\title{
MAIN TRENDS IN THE DEVELOPMENT OF THE GERMAN NEWSPAPER MARKET
}

\author{
Amin M. Eshkerat ${ }^{1}$, Anatoliy P. Danilov ${ }^{2}$, Andrey A. Danilov ${ }^{3 *}$, Margarita G. \\ Danilova ${ }^{4}$, Valeriy P. Komissarov ${ }^{5}$ \\ ${ }^{1}$ Assoc. Prof., Chuvash State University, RUSSIA, eshkeratamin@gmail.com \\ ${ }^{2}$ Head of Chair, Chuvash State University, RUSSIA, anatoliy.p.danilov@gmail.com \\ ${ }^{3}$ Prof. Dr., Chuvash State University, RUSSIA, danilov.andrey@mail.ru \\ ${ }^{4}$ Assoc. Prof., Chuvash State University, RUSSIA, danilova1956@gmail.com \\ ${ }^{5}$ Assoc. Prof., Chuvash State University, RUSSIA, valerijkomissarov134@gmail.com \\ ${ }^{*}$ Corresponding author
}

\begin{abstract}
The aim of the study is to consider issues of establishment and development of the German newspaper market in the postwar period and after the unification of Germany on a systemic level. Specific impact of these two processes on the formation of the newspaper market features in the country is revealed. Particular attention is paid to the transformation of the German newspaper market in recent years, from the late 1990s to present. During the given period, under the onslaught of new digital technologies, changes in the preferences of information consumers have been observed, especially with regard to the print media: reduction in the time for reading newspapers, decrease in circulation and advertising revenues, and the bankruptcy of several reputable periodicals. The article also focuses on the groundbreaking approaches of some newspapers and the views of experts on how to overcome the crisis of the print industry. Germany has played an outstanding role in the development of world journalism. Unification of the German lands in the second half of the nineteenth century strengthened the position of German newspapers and led to the emergence of the press barons. In the postwar period, all German print media were under strict censorship control of the British and U.S. occupation forces. The postwar development of the German media was largely determined by the political evolution of the fragmented country into two parts belonging to two coalitions. Germany had been a newspaper country for three centuries. However, at the beginning of the XXI century, the situation changed dramatically. Digital media have affected the existence of German print media. Nevertheless, the German newspaper market is still the largest in Europe and the fifth largest in the world.
\end{abstract}

Keywords: Germany, cooperation of local newspapers, nationwide editions, newspaper and advertising markets, declining circulation, transformation.

\section{INTRODUCTION}

Germany has played an important role in the development of the global journalism. It was Germany where the first factory for making papers appeared as early as in the beginning of the 14th century. Book printing was invented here in the middle of the 15th century; it was Germany where the first printed books appeared. It was here that the flying leaflets and one of the first handwritten editions of the merchant house of banker Jacob Fugger emerged. The first commercial weekly newspapers (Avisso and Relation) appeared in 
Germany at the beginning of the XVII century. These publications were closed due to the outbreak of the Thirty Years ' War in 1618-1648. This conflict eventually led to the fragmentation of Germany into many state entities and to the loss of Germany's leadership in the field of publishing.

\section{RESULTS}

The unification of the German lands in the second half of the XIX century resulted in the strengthening of the positions of German newspapers and the emergence of press barons. The increasing role of the German press is demonstrated by the activities of the publishing houses of Rudolf Mosse, Leopold Ulstein, and Bertelsmann. However, after the defeat of Germany in 1945, all mass media of Nazi Germany were closed and only a part of them was restored under the control of the Allies.

In the post-war period, all print publications in Germany were under strict censorship control of the occupying forces of Britain and the United States. At the same time, in West Germany, there were a fair number of popular British and American publications, which later became the prototypes for the new newspapers of the Federal Republic of Germany. Such newspapers include Frankfurter Rundschau (Frankfurt Review) and Suddeutsche Zeitung (South German Newspaper), founded in 1945, Die Welt founded in 1946, Abendzeitung (Evening Newspaper), founded in 1948, Frankfurter Allgemeine Zeitung (Frankfurt General Newspaper), founded in 1949.

Germany has 323 daily newspapers, 23 weekly newspapers, and six Sunday newspapers (Germany - the country of newspapers). Regional and local newspapers make up the majority of newspapers. Along with them, there are seven newspapers that are distributed at the national level and have the status of supraregional or national publications.

After the Second World War, many regional newspapers in Germany realized that they could not be profitable in small geographical markets, so they resorted to the tactic of combining several local newspapers in a chain with some large publication to combine production processes and cooperate in the advertising market.

According to E.V. Vartanova, a form of cooperation between local newspapers and major publications was prevalent already during the time of Kaiser's Germany and the Weimar Republic. Within the framework of cooperation, local newspapers produce only local material, and the rest of the content is taken without modification from a specific main publication.

As a result of the cooperation of various publications, independent editorial units (Publizistische Einheit) and full editorial offices (Vollredaktion) are formed. The full editorial board produces most of the content, while the local editorial board (Mantelredaktion) produces the local part of the content.

The development of the German media in the postwar years was largely driven by the political evolution of a fragmented country into two parts that belonged to two blocs: the German Democratic Republic (GDR), part of the Eastern Communist bloc, and the Federal Republic of Germany (FRG), part of the Western bloc. On October 3, 1990, the two parts of Germany were reunited, and on March 15, 1991, the four postwar powers that had controlled the two Germanys for 45 years relinquished their occupation rights.

The reunification of 16 million East Germans with 64 million West Germans led to the fading of the mass media of the former and the strengthening of the mass media of the latter. One of the examples is the newspaper of the GDR called Neues Deutchland, the circulation of which exceeded one million copies before the unification. However, a year after the unification, its circulation dropped tenfold to 100 thousand copies. Certainly, there was a desire of the owners of the FRG's mass media to seize the market of the eastern neighbors and the incentive for this was obvious, since there were a huge number of potential readers among the East Germans (according to statistics, about 10 million people). By the beginning of the XXI century, newspapers, magazines, and TV stations created in the former West Germany dominated the media landscape of the modern Germany.

$90 \%$ of the German population are ethnic Germans who speak German, so German-language newspapers predominate in Germany. However, along with the Germans, there are large diasporas of immigrants from Turkey, the Balkan countries, and the Arab East. The rapid economic growth of the German economy in the late 50 s and early 60 s of the last century necessitated the import of labor forces. Mainly Turkish workers were recruited to work in the German industry. As of 2019, more than three million ethnic Turks live in Germany. They are mainly concentrated in the cities of Berlin and Nuremberg. The wars in the Balkans in the early 1990 s led to the emigration of about a million refugees from this region to Germany. The ongoing conflicts in the Middle East and North Africa (in Syria and Libya) resulted in emigration of more than two million refugees to Germany. 
Finally, the provision in the German Constitution, which granted ethnic Germans who lived in other countries the right to return to their historical homeland, promoted the emigration of almost all ethnic Germans from Russia and Central Asian countries. And if we add economic emigrants from the countries of the former USSR to Germany, we will get a huge number of Russian-speaking German citizens.

At present, newspapers in Germany are printed in Turkish, Russian, Balkan languages, and Arabic. Güncel is one of the most popular Turkish-language newspapers. The most popular newspapers in Russian are Kontakt, Vostochniji Ekspresse and Russkaja Germanija.

The market of the ethnic newspapers in Germany is not the subject of our article, but we have given this brief overview to point out the important fact that this market is not saturated and that it tends to expand in the future.

Journalistic traditions in Germany can be traced back to the Weimar Republic (1919-1933), where reporting was considered less important than the work of highly professional and erudite editors. This circumstance led to the fact that German journalism was not particularly dynamic. The situation began to change after the war, when the United States and Great Britain sent a large number of reporters to Germany to work in the press services and guide the newly created German mass media, and to teach German journalists how to work in the spirit of the Western liberal school of journalism.

From a political point of view, the German mass media cover a narrower part of the political spectrum than the mass media of other Western countries. This is caused by the attempt of the German press to avoid political extremes. When covering political issues, journalistic materials are less emotional and groundbreaking than in other countries. Observers attribute such caution to the strict organizational corporate control of the press in Germany, where the opinions and criticism of journalists are combined with the opinions of editors and leading authors. This feature of the German press leads to the fact that newspapers rarely support one political party or a political candidate. In recent years, however, we can see a shift away from this practice, especially in foreign policy issues: in December 2016, for example, the editor-in-chief of Bild called Russian Foreign Minister Sergei Lavrov a war criminal. In response, Lavrov said that the Russophobia of the German media is ahead of the curve.

Since Germany is the country with the largest number of newspapers in Europe and newspapers are considered the main carrier of advertising in this country, the advertising crisis, which was most acute at the end of 2000, affected Germany more than any other European country. According to Orekhova O.E., "The crisis was a consequence of structural changes in the global mass media system. The reasons lie in the processes of differentiation of society against the background of changing the overall social conditions and in the rapid development of online and satellite forms of communication, which have greatly multiplied the range of mass media. Whereas before the beginning of the 20th century, the press was the only source of mass information, in the modern society of the 21 st century, traditional print media have to compete in the market not only with publications of their typological group, but also with electronic mass media and the cutting-edge multimedia information sources" (Orekhova, 2008, p. 28).

Statistical data from the early 1990s and data from 2019 show impressive drops in the circulation of daily and weekly periodicals. The total circulation of daily newspapers in Germany will be 27.3 million copies in 1991, and 28 years later, i.e. in 2019 - 13.5 million copies (Circulation of daily newspapers in Germany in selected years from 1991 to 2019). It is worth noting that the circulation of German newspapers declined steadily and smoothly until the beginning of the global financial crisis in 2008, but there has been a sharp decline after the crisis. As a result, in the period from 1991 to 2019, the total circulation decreased by half. According to Evgeniya Koptyug, the reasons that led to such a sharp reduction in circulation include the development of the Internet and the widespread use of mobile devices and tablets, which radically changes the preferences of information consumers, especially in relation to print mass media.

As for the daily use of multimedia, in 2019, German consumers spent an average of 236 minutes a day watching TV, 101 minutes online, 100 minutes listening to the radio, 26 minutes reading the books, and 22 minutes reading the newspapers and magazines. Smartphones (89\%), television devices (88\%), radios $(87 \%)$ dominated among the devices used for personal information consumption. As for watching TV by different age groups of the population in 2019, children aged 3 to 13 years spent an average of 64 minutes a day watching TV, compared to 84 minutes in the 14 to 29 age group. Viewers over the age of 50 spent an average of 153 minutes in front of the TV.

Viewers aged 50 and older spent an average of 153 minutes a day in front of the TV. This is quite logical, since the number of Internet users in Germany is steadily growing every year. In the last decade alone (2008-2018), the number of users has increased from 42.7 million in 2008 to 63.3 million in 2018. It is worth 
noting that the highest share of Internet users among all age groups was found among persons aged 14-29 years - almost 100\% (Media usage in Germany - Statistics \& Facts).

Reduction of the time spent for reading the newspapers is a difficult problem for the newspaper industry, especially for those newspapers that are largely financed by advertising. Some publishers have started digital subscriptions in the recent years. The USA and Scandinavian countries were the first to use the new subscription format. Currently, the New York Times newspaper has 4 million subscribers (3.1 million of them are digital subscribers), the Swedish newspaper Dagens Nyheter and the Finnish newspaper Helsingen Sanomat each have 150 thousand digital subscribers. In 2019, among the two hundred most visited newspaper sites, the New York Times ranks first in the world, the German Bild and Welt took 29th and 37th places in the world, respectively (2019 Newspapers Web rankings).

It is worth noting that Germany was very late in starting its experiments with paid access to newspaper materials on the Internet. Leading British, American, and Scandinavian publications introduced such models back in the late 1990s, and Germany only ten years later. In 2009, Axel Springer concern began charging money for access to some of the articles in the city's Berliner Morgenpost and Hamburger Abendblatt online newspapers. In 2011, Die Tageszeitung newspaper introduced a voluntary payment for the materials the users liked on the site. In 2012, the concern introduced paid access to the materials of the national newspaper Die Welt, leaving the readers access to only 20 articles per month.

Currently, there are about 700 editorial services on the Internet, including websites, E-paper, smartphone applications. Newspapers spread the news through social media on Twitter, Facebook, and Snapchat. For example, the Bild newspaper has created a Bild Mobile app for quick access to the online version from mobile phones and smartphones, and this practice tends to grow every year. Recent research shows that every second edition in Germany, realizing that the future is digital, plans to release new editorial apps online (Germany is a country of newspapers: the most important facts about the media in Germany).

Germany has been a newspaper country for three centuries; a huge number of Germans started their day with reading a newspaper at breakfast; the newspaper has been the number one daily companion and source of information. However, at the beginning of the 21 st century, the situation changed dramatically. Digital media have influenced the existence of German print media. The tradition of daily newspaper reading is gradually disappearing. As of 2019, statistics show that 41.4 million people in Germany still read newspapers several times a week in their free time, compared to 11 million who read newspapers several times a month. This trend has led not only to a decrease in the circulation of German newspapers, but also to the bankruptcy of some of them.

According to the materials of the Deutsche Welle, many German newspapers cannot withstand the onslaught of the digital era. The most dramatic bankruptcies include the bankruptcy of two high-quality newspapers Financial Times Deutschland and Frankfurter Rundschau in 2012, as well as the bankruptcy of Germany's oldest tabloid newspaper Abendzeitung in 2014. The shareholders of many publications suffer great losses. Many experts believe that some other publications will take their turn soon.

In the Federation of German Newspaper Publishers (BZDF), no one wants to talk about a pessimistic future. The press secretary of the Federation, Anne Paskey, states an obvious fact: "over the past few years, the newspaper industry has gone through a huge transformation process." In her opinion, the conceptual model of future newspapers should look like this: "several expensive high-quality newspapers with rich content for the educated elite and several cheap or even free newspapers for a mass audience, meant to be read while traveling on city trains or public transport."

\section{CONCLUSION}

The German newspaper market is still the largest in Europe and the fifth largest in the world. According to BZDF statistics, there are currently 1,532 different publications in Germany. There are 330 newspaper publishers in Germany and 130 newspapers with full editorial responsibility. However, it is getting smaller every year.

Statistics from the German Advertising Industry Association show that the volume of the German advertising market in 2018 amounted to 26.8 billion euros, and net income from advertising in the media amounted to 15.8 billion euros. During the period from 2009 to 2018, the share of newspapers in the advertising market decreased from 24 to $14 \%$. It is worth noting that television in 2018 had the highest share of the advertising market with 29\% (Advertising market share in Germany 2009-2018, by media type). 


\section{ACKNOWLEDGEMENT}

The reported study was funded by RFBR and Chuvash Republic according to the research project № 19412-210003.

\section{REFERENCE LIST}

1. 2019 Newspapers Web rankings. Available by: https://www.4imn.com/top200.

2. Advertising market share in Germany 2009-2018, by media type. Available by: https://www.statista.com/statistics/411018/advertising-media-type-market-share-germany.

3. Circulation of daily newspapers in Germany in selected years from 1991 to 2019. Available by: https://www.statista.com/statistics/380784/circulation-daily-newspapers-germany.

4. Germany - the country of newspapers: the most important facts about the media in Germany . Available by: https://www.deutschland.de/ru/topic/kultura/gazety-i-svoboda-pecati-v-germanii.

5. Germany is a country of newspapers: the most important facts about the media in Germany. Available by: https://www.deutschland.de/ru/topic/kultura/gazety-i-svoboda-pecati-v-germanii.

6. Media usage in Germany - Statistics \& Facts. Published by Evgeniya Koptyug, Oct 23, 2019. Available by: https://www.statista.com/topics/5053/media-usage-in-germany.

7. Orekhova O. E. (2008) German print media in a socially divided society. 